Дубень Андрей Кириллович

Младший научный сотрудник

Институт государства и права

Российская академия наук

\title{
ОСОБЕННОСТИ ЭЛЕКТРОННОГО ИСПОЛНИТЕЛЬНОГО ПРОИЗВОДСТВА В РАМКАХ ЗАОЧНОГО ПРОИЗВОДСТВА В ГРАЖДАНСКОМ ПРОЦЕССЕ
}

Аннотация: В статье исполнительное производство рассматривается как заключительная стадия гражданского процесса, основная задача которого заключается в обеспечении исполнении заочного решения, вместе с тем анализируется процесс применения информационных технологий в деятельности судебных приставов. В работе проанализированы актуальные проекты нормативных актов, автор пришел к выводу, что применение и использование новых технических средств возможно на всех этапах принудительного исполнения судебных актов.

Ключевые слова: исполнительное производство, заочное производство, электронное исполнительное производство, заочное решение.

Keywords: enforcement proceedings, correspondence proceedings, electronic enforcement proceedings, correspondence decision.

Электронное исполнительное производство является одним из значимых элементов развития судебной системы. Использование информационных технологий в деятельности судебных приставов обуславливают актуальность вопроса об использовании сведений в электронной форме в целях исполнения судебного решения в онлайн-режиме.

В Российской Федерации исполнительное производство сопровождается развитием эффективной системы межведомственного электронного взаимодействия [1, с. 39]. На сегодняшний день действует Положение о системе межведомственного электронного документооборота между Федеральной службой судебных приставов и Федеральной налоговой службой, которая предусматривает взаимодействие по передаче информации в электронной форме между судебными приставами и кредитными организациями [2].

В соответствии с Гражданским процессуальным кодексом Российской Федерации и Федерального закона «Об исполнительном производстве» для возбуждения 
исполнительного производства необходимо предоставить оригинал исполнительного документа, соответственно, информирование сторон исполнительного производства в электронном виде и направление заявлений в электронном виде законодательно не предусмотрено, за исключением некоторых случаев, предусмотренных в законе.

Рассматривая институт заочного производства следует отметить, что заочное решение вступает в законную силу по истечении всех сроков, в течение которых решение может быть обжаловано. К ним относятся срок для подачи заявления об отмене заочного решения суда в течение семи дней со дня вручения ему копии этого решения, а также срок в один месяц для обжалования в апелляционном порядке по истечении срока подачи ответчиком заявления об отмене этого решения суда, а в случае, если такое заявление подано, - в течение месяца со дня вынесения определения суда об отказе в удовлетворении этого заявления. Вступление решения в законную силу влечет определенные правовые последствия, которые заключаются в том, что решение приобретает свойства обязательности, неопровержимости, исключительности, а также исполнимости. Основной проблемой данного процессуального института в рамках исполнительного производства является отсутствие сведений у ответчика о вступлении в законную силу заочного решения суда.

Вместе с тем, неизбежным следствием информационной модернизации судебного процесса является недоступность получения информации об исполнении судебного решения в рамках заочного производства. Пользователи сети Интернет и непосредственно участники судебного разбирательства испытывают трудности по получению информации.

Согласно Федеральному закону от 12 ноября 2019 г. № 375-Ф3 «О внесении изменений в Федеральный закон «Об исполнительном производстве» в целях взаимодействия гражданина с приставом и повышения подотчетности судебного пристава гражданам, интересы которых он обязан защищать созданы системы персонального электронного кабинета [3]. Так, любая информация, в том числе процессуальные документы, получаемые в ходе исполнительного производства, будут доступны сторонам в форме электронных документов. Однако данный законопроект не учитывает отсутствие информационных технологий в труднодоступных и удаленных населенных пунктах, а также невозможности получения данных об ответчике, который ранее не присутствовал в судебном процессе. Все это вызывает у судебных приставов проблемы в части документального подтверждения задолженности и возможности исполнения судебного решения в онлайн-режиме. 
На наш взгляд, судебный пристав, в случае неполучения документов должником в электронной форме, должен будет принимать меры к уведомлению по иным адресам (по информации взыскателя, данным ЕГРИП или ЕГРЮЛ) либо по иным способам, к примеру, по простой почтовой корреспонденции, СМС - оповещению либо автоматический обзвон. Так при разработке данного законопроекта не учитывались отдельные аспекты, в частности полный доступ всех граждан к сети Интернет. В связи с этим, считаем необходимым отдельно определить правовой статус, как граждан, не имеющих доступ в Интернет в электронном исполнительном производстве, так и меры, которые должны применять судебные приставы исполнители в таких случаях.

Таким образом, пользователи сети Интернет и непосредственно участники судебного разбирательства испытывают трудности по получению информации об исполнении судебного решения.

Для более правильного понимания проблемы мы провели эксперимент по поиску данных о должниках в банке исполнительных производств. Нами были изучены заочные решения судов 2019 и 2020 гг. на сайтах: районного суда г. Симферополь (Республика Крым) и районного суда г. Тулы.

Так, на официальном сайте Железнодорожного районного суда г. Симферополь (Республика Крым) в графе судебное делопроизводство по случайной выборке было взято гражданское дело (№ 2-1087/2020) о взыскании задолженности по договору аренды транспортного средства, для поиска должника в банке данных исполнительных производств. Данное дело было рассмотрено в 2020 г. [4]. Поиск осуществлялся на официальном сайте федеральной службы судебных приставов. При запросе поиска банк данных указал, что ничего не найдено.

При этом, в Центральном районном суде г. Тулы гражданское дело о расторжении договора о передаче личных сбережений, взыскании денежных средств по договору займа (№ 2-3018/2019) было рассмотрено в 2019 г., стороны решение не обжаловали [5]. При этом в банке исполнительных производств отсутствуют какие-либо сведенья о должнике.

На сегодняшний день участники судебного разбирательства не всегда имеют возможность на официальном сайте отследить информацию об исполнении судебного акта. Так, при поиске фамилии должника достаточно часто сайт исполнительного органа выдает ошибку либо указывает об отсутствии сведений. Специалисты в области информационных технологий пытаются решить вопрос об обеспечении свободного 
доступа граждан к получению соответствующей информации об исполнительном производстве, что подтверждает актуальность данной проблемы.

Другой немаловажной проблемой в исполнительном производстве в рамках заочного производства является порядок взыскания криптовалюты у должника, хранящихся в интернет - небанковских организациях.

Так, 2020 году суд апелляционной инстанции рассмотрел гражданское дело в заочном порядке, в котором, должник признал себя владельцем криптокошелька и предоставил суду заверенный нотариусом скриншот кошелька с паролем [6]. При этом в апелляционной жалобе должник указал на незаконность заочного решения суда, согласно позиции должника им была совершена сделка по продаже криптовалюты, который добровольно перечислял принадлежащие ему денежные средства на счета третьих лиц. При этом недобросовестный должник отказался от предоставления логина и пароля к криптокошельку, соответственно, будет взыскать криптовалюту с должника.

Ввиду использования цифровой валюты в сети Интернет, требуется дополнить Федеральный закон «Об исполнительном производстве», положением о криптовалюте. Считаем необходимым предусмотреть реестр криптокошельков, который будет идентифицировать граждан по паспорту и идентификационному номеру налогоплательщика (ИНН), так криптоинвестор обязан проходить сертификацию с целью вложение денежных средств в криптокошелек. На наш взгляд, данный реестр должен вестись Банком России, который осуществляет единую денежно-кредитную политику и регулирует все финансовые операции в стране, одновременно с этим доступ в данный реестр будет открыт и для исполнительных органов. Таким образом, реест криптокошельков исключит анонимность расчетов и позволит судебным приставамисполнителям получать сведения о финансовых активах должника при исполнительном производстве и взыскивать криптовалюту с должника в размере задолженности необходимые для исполнения требований.

Таким образом, в целях совершенствования электронного исполнительного производства считаем необходимым внести следующие дополнения в Федеральный закон «Об исполнительном производстве»»:

1) В статье 24 дополнить частями 1.1 следующего содержания:

В случае отсутствие у лица, участвующий в исполнительном производстве информационно-телекоммуникационной сети и инфраструктуры, обеспечивающей информационно-технологическое взаимодействие, судебный пристав - исполнитель 
обязан известить этого лица путем отправки СМС - сообщения либо телефонограммой с использованием почтовой, и иных видов связи.

2) Ввести новую статью 70.1 и изложить в следующей редакции:

Ведение реестра криптокошельков осуществляется Банком России в единой информационной системе.

Сведения, содержащиеся в реестре криптокошельков, должны быть доступны для Федеральной службы судебных приставов в единой информационной системе.

Цифровая валюта (криптовалюта) обнаруженная у должника, хранящаяся в криптокошельке и занесенная в реестр, изымается, о чем составляется соответствующий акт. Изъятая цифровая валюта передается для обмена в обменные пункты, которые осуществляют обмен цифровой валюты и перечисляют полученные от продажи денежные средства в рублях на указанный в постановлении судебного пристава.

Считаем, что данные нововведения позволят упростить и сделать более оперативной всю систему обмена информацией и взаимодействия гражданина с судебным приставом, что, безусловно, будет способствовать повышению эффективности деятельности Федеральной службы судебных приставов и уровня реализации прав и законных интересов граждан на территории Российской Федерации.

\section{Литература:}

1. Тоукола Ю.М. Исполнительное производство в обществе будущего, технологическое развитие и гражданские права // Принудительное исполнение актов судов и иных органов в отношении юридических лиц (организаций и предпринимателей). Проблемные аспекты : сб. материалов Междунар. науч.-практ. конф., 4-8 июня 2012 г., Воронеж. - М.: Статут. - 2013. - С. 37-42.

2. Постановление Правительства РФ от 22 сентября 2009 г. № 754 «Об утверждении Положения о системе межведомственного электронного документаоборота» // Собрание законодательства Российской Федерации. - 22 сентября 2009 г. - №25. - Ст. 2576.

3. Федеральный закон от 12 ноября 2019 г. № 375 Ф3 «О внесении изменений в Федеральный закон «Об исполнительном производстве» // Собрание законодательства РФ. 2019. № 41. Ст. 4840.

4. Решение Железнодорожного районного суда г. Симферополь Республики Крым № 2-1087/2020 от 30 июля 2020 г. // СПС «КонсультантПлюс».

5. Решение Центрального районного суда г. Тулы Тульской области № 2-3018/2019 от 18 декабря 2019 г. // СПС «КонсультантПлюс».

6. Апелляционное определение Нижегородского областного суда № 33-11104/2020 (2-4875/2019) от 24 ноября 2020 г. // СПС «КонсультантПлюс». 